\title{
RURAL AREAS IN MACEDONIA AS TOURISM SUPPLY: PROBLEM OR A CHALLENGE?
}

DOI: http://dx.doi.org/10.18509/GBP.2019.80

UDC: 338.48-6:379.845]:332.12(497.7)

\author{
Biljana Petrevska ${ }^{1}$ \\ Nikola Dimitrov ${ }^{1}$ \\ Aleksandra Terzić ${ }^{2}$ \\ ${ }^{1}$ Faculty of Tourism and Business Logistics, Goce Delčev University - Štip, Macedonia \\ ${ }^{2}$ Geographical Institute "Jovan Cvijić" Serbian Academy of Sciences and Arts, Belgrade, \\ Serbia
}

\begin{abstract}
The fact that Macedonia has unique and well-preserved natural resources, large number of traditional rural households and much supplementary potential, imposes great future challenges towards rural tourism development. Moreover, due to ever-growing interest of international market in rural lifestyle, rural tourism sounds like inevitable alternative for economic development. The paper uses a qualitative approach to illustrate the ambient for development of tourism in rural areas in Macedonia. In this respect, the research outlines the current possibilities seriously to consider rural areas to be added to the current tourism supply in Macedonia, by highlighting the barriers of rural tourism from a perspective of a problem or a challenge. The paper points out that Macedonia needs to undertake serious measures and activities on central and local level for incorporating many rural areas in enriching tourism supply and boosting modest tourism development.
\end{abstract}

Keywords: Limitations; Rural areas; Tourism development.

\section{INTRODUCTION}

Rural tourism is very popular in the international tourism market, and occurs in almost every country, particularly in Europe which became the world leader. It is often seen as a key solution to creating jobs and raising living standard and local economic development. Being able to be developed with relatively little investment credit, training, and capital, are main advantages of rural tourism. It is less costly, need not involve dependency on outside firms and their decisions on whether they want to be in an area, and provides a base for these small businesses that might not otherwise be in rural communities because of their small populations.

Macedonia has 2,075,301 inhabitants out of which 17.6\% live in pure rural municipalities, $99.5 \%$ of rural economy encompasses individual rural enterprises, and $27.1 \%$ of poor population live in rural areas. The ratio urban-rural population changed over the years, from $74: 26$ in $1948,58: 42$ in 2002 , to $68: 31$ in 2008 . There are 1,767 settlements in Macedonia, out of which 34 urban and 1,733 rural settlements. The fact that Macedonia has unique and well-preserved natural resources, large number of traditional rural households and much supplementary potential, imposes great challenges for rural tourism development. Yet, unlike many countries which discover the benefits of rural tourism over local and regional tourism development, Macedonia notes modest results in this area. The heterogeneous landscape, field configuration, natural resources as well as 
ethnography support the necessity of implementing planning process in introducing and developing rural tourism development.

The objective of this paper is to illustrate the ambient for development of tourism in rural areas in Macedonia by highlighting the barriers of rural tourism from a perspective of a problem or a challenge. For this purpose, the paper applies the qualitative approach in outlining the current possibilities seriously to consider rural areas to be added to the current tourism supply in Macedonia.

The paper is structured in several parts. After the introductory part, Section two presents the literature review. The general framework for rural tourism development in Macedonia is noted in Section three, while the barriers and challenges are presented in the last section. The paper contributes to the literature review on the rural tourism in Macedonia, along with some findings [6] and [16].

\section{LITERATURE REVIEW}

A research literature has emerged on the concept of rural tourism. Its complex nature (Figure 1) results with many links among the elements and issues, thus making its defining very problematic. So, in order to describe tourism in rural areas, many terms are used, like: farm tourism, green tourism, soft tourism, country experience, ecotourism, etc. A variety of interpretation is offered but generally includes activities and interests in farms, nature, adventure, sport, health, education, arts, and heritage. It was found that rural areas often build tourism due to the existence of local amenities like historical sites, natural beauty, and clean air [9]. To that [11] and [14] add cultural traditions and values, while [25] and [15] further include family patterns, folklore, social customs, museums, monuments, historical structures and landmarks. This was further developed by [24].

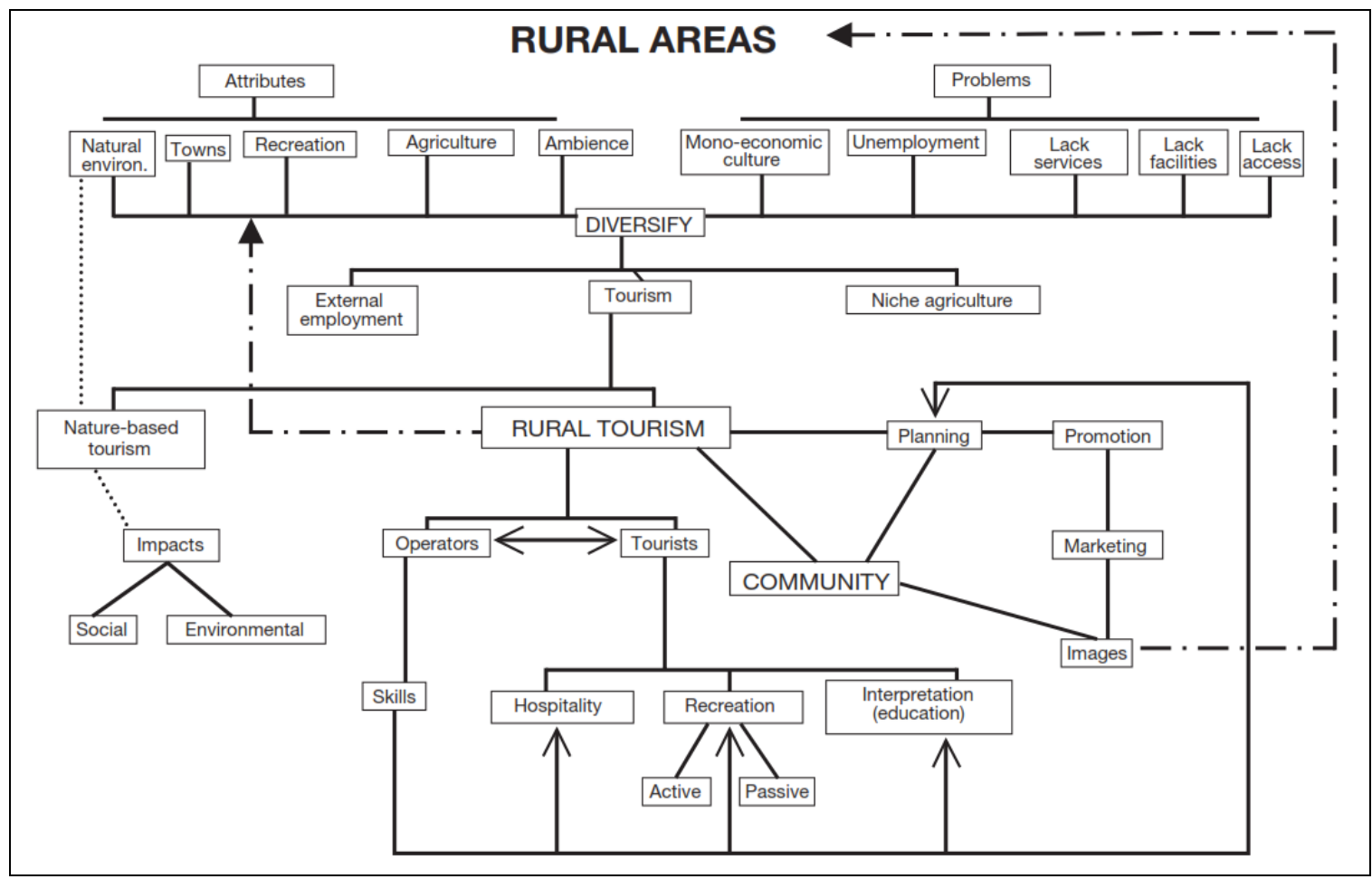

Figure 1. Complex nature of rural tourism

Source: [1] p. 143 
Over the years, rural areas were often faced with many changes that limited their developing options and forced them to look for nontraditional ways to sustain themselves [7], [23] and [26]. So, they found tourism to be a challengeable tool for creating jobs and raising living standard. This was particularly the case for many economically and socially depressed rural areas [2], [4-5], [8], [10] [12], [17-18], [20-22]. Rural areas realize that possess many alternative sources (like tradition, culture, and heritage) which may enable them to sustain local economies and to encourage local development [13], [19].

\section{GENERAL FRAMEWORK FOR RURAL TOURISM IN MACEDONIA}

Early 2000s may be noted as years for beginning of rural tourism development in Macedonia, generally initiated by donor funded projects. From a logistic point of view, this issue generally is covered by the Law on tourism (2004), Law on hospitality (2004) and Law on tourism development zones (2012). This urged the need of preparing many key documents related to rural tourism development on various levels. In this regard, Macedonia has many strategic documents, like: National strategy for regional development 2009-2019, National strategy for sustainable development 2009-2030, National strategy for tourism 2016-2021 and National strategy for rural tourism 20122017. Furthermore, the municipalities develop strategic documents on local level, like local economic development strategies, local action plans, annual programs, etc. They also develop various studies and documents for developing tourism and some specific tourism forms for the destinations.

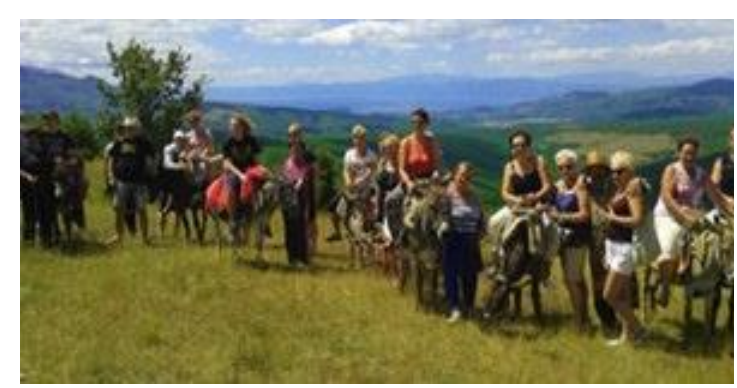

a) Donkey safari in village Kuratica (Ohrid)

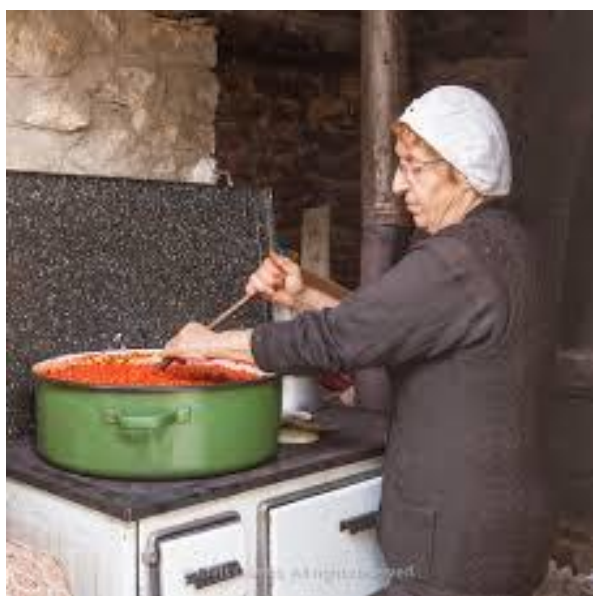

c) Cooking ajvar in village Dihovo (Bitola)

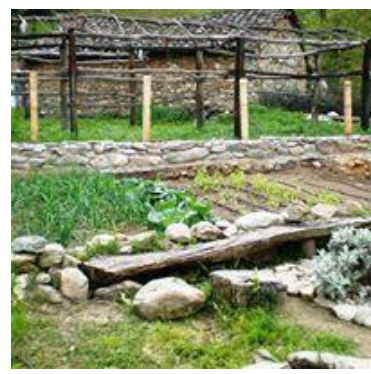

b) Garden for organic food, village Omorani (Časka)

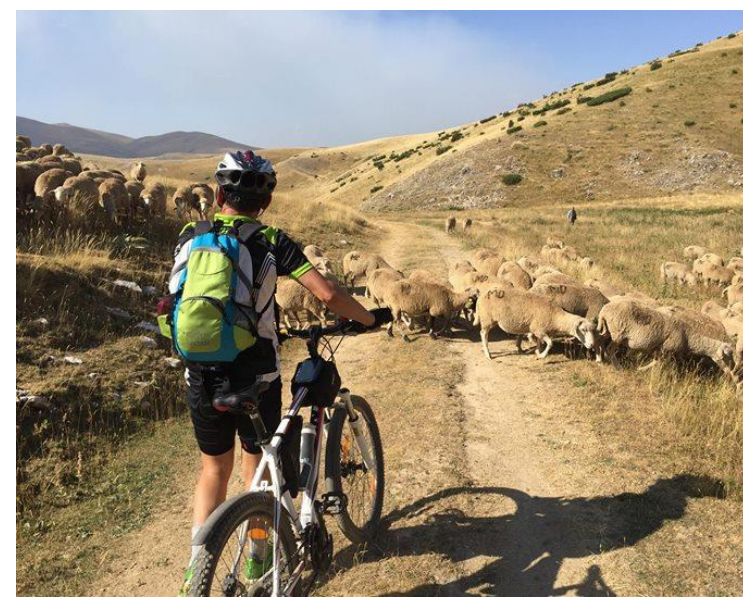

d) Mountain bike-ride, village Tresonče (Mavrovo Rostuša)

Figure 2. Selected examples of rural tourism activities in Macedonia 
Several key institutions on various levels are responsible for rural development issue in Macedonia. The national policy level consists of the Ministry of economy, Ministry of agriculture, Ministry of transport and communications (for the issues of infrastructure, airports, loans), Agency for tourism promotion, Agency for support of agriculture development, Agency for financial support of underdeveloped agricultural regions, etc. The regional policy level consists of regional development centers and local branch offices of the ministry of agriculture. The local executive policy level is consisted of municipalities, local action groups (NGOs), and various local networks for rural development. There is also a cross level (policy and executive) actors, like: the donors (EU, GIZ, UNDP, SDC, SIDA, SWG, USAID, World Bank), tourism chambers, educational institutions, business sector (providers, guides, locals, farmers, etc.), etc.

Figure 2 presents some positive examples of individual initiatives of rural tourism in Macedonia. They all offer to tourists pleasant experiences related to the natural environment, historic heritage, and cultural patterns [3], along with offering adventure, sports, festivals, crafts, and general sightseeing. Having in mind that culture, tradition and heritage are often well preserved in rural and peripheral areas, they become valuable resources for their socioeconomic development.

\section{BARRIERS AND CHALLENGES FOR RURAL TOURISM}

Rural areas in Macedonia are facing some general weaknesses that have negative profound impact over its development, like: decrease in rural population; unfavorable age structure; small and old households; unfavorable educational structure; lethargy; lack of awareness; lack of finance; new professions etc. In this line, the current potential threats may act as additional barriers for rural tourism, like: conflicts between local community and tourists; marginalization; neglecting traditions; lack of coordination between old and new approach of tourism development; competition to other tourism types; degradation of natural and anthropogenic surrounding; fear of new way of thinking and acting; migration and depopulation etc. Hence, further development in rural tourism strongly depends on:

- The public policies directed towards specific investments tailored according to the needs of specific region;

- Efforts to increase tourist accommodation capacity and occupancy rate; and

- Significant efforts to increase rural tourism income as a precondition for regions' tourism development.

On the other side, some positive impulse occur in the attempt Macedonia to address rural tourism as part of a comprehensive regional development strategy. In this context, following challenges arise: investments; popularity; short vocations; new frontiers; employment; new technologies; categorization; local food; tourism clusters; package tours; differentiation in tourism supply, etc.

It is pointlessly to have excellent natural surroundings, firm catering resources and steady accommodation capacities if additional institutional support is missing. In this line, the central and local government may raise initiatives for strengthening and enhancing existing status of rural tourism. So, current diversified structure of attractiveness should be accompanied by an adequate policy since poor investments result with poor development.

Consequently, one may argue the necessity of introducing different fiscal and economic measures, like: subsidies, subventions, tax deductions, employment opportunities, revision and control, etc. Furthermore, there is an urgent need for taking measures in: 
infrastructure improvement, accommodation renovation, improvement of electricity empowering system, reanimation of private sector in rural communities, revival of neglected and forgotten traditional professions, education and training on positive effects of rural tourism, preservation of natural, anthropogenic and cultural values etc. Further in this context, some similar supportive measures and activities may be introduced, like: the need for starting-up tourist agencies with rural tourism supply or demand as their main scope of work; creating specific profile of rural tourist guide, as well as strengthening human resources by introducing rural tourism police, managers of rural tourism zones and other experts in the field of rural catering.

Various activities have been already practiced in some rural areas in Macedonia, or can be further introduced to enrich tourism supply, like: cheese-making at a local goat/sheep farm, giving cooking classes for cooking various local traditional Macedonian specialties or doing some traditional activities like knitting, herbs and plants picking and making personal organic cosmetic products, bird watching, photo sessions in the nature, selfaromatherapy hours and weekends, traditional fishing walk to natural waterfalls and caves, hiking and mountain climbing with a tour guide, donkey-ride, jeep safari to hunting reserves, etc.

\section{CONCLUSION}

Rural areas in Macedonia do possess various attractions (the natural and manmade features both within and adjacent to a community) and offer satisfactory hospitality to tourists (both, by community residents, and employees in tourism businesses and attractions). On the other hand, tourism infrastructure, like: access facilities (roads, airports, trains, and buses) water and power services, parking, signs, and recreation facilities needs substantial improvements. This also stands for the services, like: lodging, restaurants, and the various retail businesses that take care of tourists' needs. The final component needed for successful rural tourism development is the promotion in terms of marketing of a community and its tourism attractions to potential tourists.

Despite many efforts in creating a base for rural tourism development in Macedonia, still more needs to be done. Many ongoing projects should be further supported by the donors, upgraded and implemented by the regional development centers of the planning regions. Such is the project for developing a register of potentials that are especially important for rural tourism as an inventory list that will add to the current tourism supply of many regions in Macedonia. When having a comprehensive data on various aspects related to rural tourism development, one may focus on specific area, like: environment, population, economic activity, production and services, access, transport and travel, culture, cultural activities, sport and recreation, accommodation and restaurants, attendance of tourists and tourist consumption. Hence, the modest up-to-date results in this area, urges the necessity for identifying effective strategic framework for enhancing rural tourism.

\section{REFERENCES}

[1] Beeton, S. Community development through tourism, Landlinks Press, Collingwood, Australia, 2006.

[2] Blaine, T. \& Golan, M. Demand for Rural Tourism: An Exploratory Study, Annals of Tourism Research, vol. 20, pp 770-773, 1993. 
[3] Butler, R. \& M. Hall. Conclusion: The Sustainability of Tourism and Recreation in Rural Areas. In: Tourism and Recreation in Rural Areas, R. Butler, M. Hall and J. Jenkins, eds., pp. 249-258. Toronto: Wiley, 1998.

[4] Chuang, S. T. Rural tourism: perspectives from social exchange theory, Social Behavior and Personality, vol. 38(10), pp 1313-1322, 2010.

[5] Dernoi, I. About Rural and Farm Tourism, Tourism recreation research, vol. 16(1), pp 3-6, 1991.

[6] Dimitrov, N. \& Petrevska, B. Rural tourism development zones: the case of Macedonia, Researches review of the Department of geography, tourism and hotel management, vol. 41, pp 152-162, 2012.

[7] Flora, C. B. \& J. L. Flora. Characteristics of Entrepreneurial Communities in a Time of Crisis, Rural Development News, vol. 12(2), pp 1-4, 1988.

[8] Fleischer, A. \& D. Felsenstein. Support for Rural Tourism: Does it Make a Difference?, Annals of Tourism Research, vol. 27, pp 1007-1024, 2000.

[9] Fredericks, M. Rural Tourism and Economic Development, Economic Development Quarterly, vol. 7, pp 215-226, 1993.

[10] Hall, D. \& Richards, G. Tourism and sustainable community development, London, 2002.

[11] Hardy, D. Historical Geography and Heritage Studies, Area, vol. 20, pp 333-338, 1988.

[12] Hill, B. The Future of Rural Tourism, Washington DC: Department of Parks and Recreation, 1993.

[13] MacDonald, R. \& Jolliffe, L. Cultural rural tourism: Evidence from Canada, Annals of Tourism Research, vol. 30(2), pp 307-322, 2003.

[14] Millar, S. Heritage Management for Heritage Tourism, Tourism Management, vol. 10(3), pp 9-14, 1989.

[15] Pedford, J.Seeing is Believing: The Role of Living History in Marketing Local Heritage. In: The Marketing of Tradition, T. Brewer, ed., pp. 13-20. Enfield Lock: Hisarlink Press, 1996.

[16] Petrevska, B. \& Dimitrov, N. Planning rural tourism development in Macedonia, Journal of Process Management - New Technologies, vol. 1(3), pp 63-68, 2013.

[17] Ploeg, J. D. \& Renting, H. Impact and potential: A comparative Review of European Rural Development Practice, Sociologia ruralis, vol. 40(4), pp 529-543, 2000.

[18] Ploeg, J. D., Renting, H., Bruner, G., Knickel, K., Manion, J., Marsden, T., Roest, D. K., Sevilla-Guyman, E. \& Ventura, F. Rural Development: From Practices and Policies towards Theory, Sociologia ruralis, vol. 40(4), pp 391-408, 2000.

[19] Prohaska, S. Trends in Cultural Tourism. In Island Tourism: Management Principles and Practice, M. Conlin and T. Baum, eds., pp. 33-51. London: Wiley, 1995.

[20] Roberts, L. \& Hall, D. Rural Tourism and Recreation: Principles to Practice, CABI Publishing: Wallingford, 2001.

[21] Simpson, M. C. Community benefit, tourism initiative: A conceptual oxymoron, Tourism Management, vol. 29, pp 1-18, 2008.

[22] Sharpley, R., J. Sharpley \& S., Page. Rural Tourism: An Introduction. London: International Thomson Publishing, 1997.

[23] Shaw, G. \& A. M. Williams. Critical Issues in Tourism. Oxford, UK: Blackwell, 1994.

[24] Turnock, D. (1999). Sustainable Rural Tourism in the Romanian Carpathians. Journal, 165, 192-199.

[25] Weiler, B. \& C., Hall. Special Interest Tourism. London: Belhaven, 1992.

[26] Williams, A. M. \& G. Shaw. Tourism: Candy floss Industry or Job Generator?, Town Planning Review, vol. 59(1), pp 81-104, 1988. 